\title{
Sketch of the history of telegraphic communication between the United Kingdom and India
}

General Sir R. Murdoch Smith K.C.M.G.

To cite this article: General Sir R. Murdoch Smith K.C.M.G. (1889) Sketch of the history of telegraphic communication between the United Kingdom and India, Scottish Geographical Magazine, 5:1, 1-11, DOI: 10.1080/00369228908732338

To link to this article: http://dx.doi.org/10.1080/00369228908732338

Published online: 27 Feb 2008.

Submit your article to this journal $\sqsubset$

Џll Article views: 10

Q View related articles $\square$ 


\title{
THE SCOTTISH
}

\section{GE O G R A P H I C A L}

\author{
MA GAZINE.
}

\section{SKETCH OF THE HISTORY OF TELEGRAPHIC COMMUNICA- TION BETWEEN THE UNITED KINGDOM AND INDIA.}

(Read at Meeting of Society, 13th December 1888.)

By General Sir R. Murdoch SMith, K.C.M.G.

To the present generation, the telegraphs to India and the Far East on the one side, and to America on the other, seem as commonplace as those which connect the different cities of the United Kingdom. Early failures are long since forgotten, and we accept the marvellous abridgment of space with which we are now familiar as the most natural thing in the world, as a sort of spontaneous growth or outcome of the spirit of the nineteenth century. Success, however, preceded as it was by costly failures, was only achieved by dint of persistent personal efforts, by individuals most of whom have already passed away. I propose on the present occasion to give a short account of those efforts, and of the difficulties which had to be overcome in the case of the telegraphic system between the United Kingdom and India. I confine myself to this particular system for several reasons. Of all the great inter-continental telegraphs, that which connects us with India is the most important for the general interests of the Empire. This would be the case even if India alone were concerned, but its importance is vastly enhanced by the fact that upon it also depends our communication with the Straits Settlements, the Australian Colonies, China, and Japan. Secondly, the telegraph to India was the first of the great inter-continental telegraphs, in point of time, to be successfully established. Lastly, through the accident of my connection with it from its first beginning until quite recently, I happen to be familiar with its history.

The first idea of connecting England with India by telegraph began to take shape during the great crisis of the Mutiny thirty-one years ago, when the necessity for such means of communication had become painfully 
manifest. By the most rapid means then in existence it took nearly three months to get answers to communications passing between London and Calcutta-a time more than sufficient for the loss of an empire.

The line chosen for the projected telegraph was naturally that of the Overland Route. This involved the laying of long submarine cables in the Mediterranean, the Red Sea, and the Indian Ocean. The failure of the first Atlantic cable had, however, so disheartened the public that submarine cables were regarded as investments of too hazardous a nature to be undertaken by prudent people without special guarantees. Unaided private enterprise could consequently not be expected to undertake the great risk of a telegraph line to India, more especially of the portions in the Red Sea and the Indian Ocean. In the Mediterranean a beginning had already been made by a private company whose cable from Marseilles to Malta it was hoped would be extended to Alexandria. Following the system adopted in the case of the Indian railways, the Red Sea portion was constructed and laid in 1859, with a Government guarantee of 5 per cent., shared equally between the Imperial and the Indian Treasuries. The cable, however, had barely fulfilled the conditions required by the terms of the guarantee when it collapsed, leaving the British and Indian Exchequers burdened until the present day, and for some years yet to come, with an annual payment of $£ 18,000$ each. Shortly afterwards, viz. in 1861, the Mediterranean Company laid a short-lived cable from Malta via Tripoli and Benghazi to Alexandria.

Warned by the costly failure of the Red Sea route, the Government of India turned their attention to the Persian Gulf. With the aid of the British detachment, who had charge of the telegraplss established in Turkey for military purposes during the Crimean war, the Turkish Government had shortly before this time erected a line from Constantinople across Asia Minor and down the valley of the Tigris to Baghdad. This line, it was thought, might by arrangement with the Turkish Government, be extended to the head of the Persian Gulf, and a cable be laid thence to the most western point which could practically be reached from India by a land line along the coast of Beluchistan. Negotiations were accordingly opened at Constantinople with a view to the accomplishment of this project, and a careful survey of the bottom of the Persian Gulf was ordered to be made. The general direction of the scheme was placed in the hands of the late Colonel Patrick Stewart, R.E., C.B., a most distinguished officer, who had already given signal proof of remarkable energy and capacity while in charge of the field telegraphs during the Sepoy war. The negotiations at Constantinople resulted after some time in a convention which provided for the erection, with British assistance, of a line from Baghdad vid Busreh to Fao, at the mouth of the Shat el Arab or united Tigris and Euphrates. Colonel (now Sir) Frederic Goldsmid, then Collector of Karachi, was instructed to proceed along the coast of Beluchistan to ascertain the exact political condition of each district, and to make arrangements by subsidies or otherwise, with the local chiefs for the protection of the proposed land line. This task-thanks to tact and diplomatic skill-he successfully accomplished, and in accordance with his report it was decided to construct a line from 
Karachi along the Mekran coast (as this part of Beluchistan is generally called) as far west as Gwadur, a fishing village in the occupation of the Sultan of Muscat. The gap from that point to Fao it was decided to fill up by means of a submarine cable, to be manufactured and laid at the expense of the Indian Government, without the intervention of a guaranteed private company.

The project therefore at this time (1862) stood as follows :- - 1st, The lines as they then existed between London and Constantinople; $2 \mathrm{~d}$, a Turkish line already opened between Constantinople and Baghdad; 3d, a line to be made with British help from Baghdad to Fao; 4th, a submarine cable to be laid from Fao to Gwadur; and 5th, a land line to be erected from Gwadur to Karachi. From London to Constantinople there was no special organisation for the transmission of international traffic. Each State had its own system adapted to suit its own internal requirements. From Constantinople to Fao the Turkish Government retained the entire charge and working of the line in their own hands. From London to the head of the Persian Gulf messages would consequently have to undergo most varied treatment, and be transmitted by clerks of many nationalities, all totally unacquainted with the language in which the telegrams were written. It was hoped that when through communication was once opened the different Governments concerned would be induced to give special facilities for the transit of Indian messages. One of the sections, however, above enumerated-that, namely, in Turkish Arabia, from Baghdad to Fao-was thought likely to prove very unsafe, and liable to constant interruption at the hands of the lawless Arab tribes of Mesopotamia. It was therefore deemed advisable to open negotiations at the Court of Teheran with a view to obtaining an alternative line between the Persian Gulf and Baghdad through Persia. The negotiations, however, seemed very unpromising, and not likely to lead to any practical result.

Such were the projects and prospects (not very bright it must be confessed) of telegraphic communication with India when Colonel Patrick Stewart assumed general charge of the scheme in 1862. Accompanied by Major (afterwards Sir John) Bateman Champain, R.E., he went to Persia for the purpose of examining the country from a telegraphic point of view, and of ascertaining what prospect there was of a satisfactory arrangement being made with the Persian Government, without which all idea of a line through that country was, of course, out of the question. The situation of the principal cities in Persia, which it was presumed the Persian Government would naturally wish to connect with the capital, Teheran, by means of the proposed telegraph, at once indicated the route which the line should follow, viz., Bushire, Shiraz, Ispahan, Teheran, Hamadan, Kermanshah, Baghdad, a distance of about 1300 miles. On reaching Teheran, however, Colonel Stewart found there was little prospect of a practicable telegraph convention being agreed to. The Persian ministers were naturally somewhat suspicious of our motives and objects, and made all kinds of impracticable proposals in order, as was supposed, to delay or defeat the scheme we were pressing on their attention. Their policy appeared so clearly to be what in parliamentary language would now be called 
"obstruction," that Colonel Stewart determined to go straight to London to push on the main and original portions of the project, viz. the BaghdadFao land line, the Fao-Gwadur submarine cable, and the Gwadur-Karachi land line, leaving Major Champain to go over the Teheran-Baghdad route, and then follow him to London.

The Convention with Turkey having by this time been signed, steps were at once taken to get the manufacture of the Fao-Gwadur cable begun, and the materials prepared for the Baghdad-Fao and GwadurKarachi land lines. When these operations were approaching completion, news was unexpectedly received of the signature of a Telegraph Convention at Teheran, which revived the all but abandoned project of an alternative line through Persia. As the main line through Turkey ultimately fell into practical abeyance, and the Persian line became the main channel of communication, it is of some interest to recall the terms of this first Persian Telegraph Convention. The idea of our erecting and working a line in Persia was by it entirely set aside. On the other hand Persia undertook, on our providing the wire and insulators (the cost of which she was to repay by instalments), to make and work a line herself from Bushire via Teheran to Baghdad, and to allow us, at a tariff to be fixed afterwards, to have our Indian messages transmitted by its means. The only intervention on our part provided for by the Convention was the presence of one English officer for a limited period in Persia to advise as to the best method of construction. Unpromising as such a Convention was, it was decided to take action on it, in the hope that something more practical might therefrom be ultimately evolved.

By the middle of 1863 the manufacture of the cable had been all but completed; the sailing vessels in which it was to be conveyed to the Persian Gulf had been chartered and fitted for its reception ; the Mekran coast land line had been fairly begun; and the materials for the Mesopotamian and Persian land lines had been got ready for shipment. The staff of the various sections had also been appointed-some in England, some in India - and all started for their several destinations before the end of the year.

The year 1864 was almost entirely spent in construction work on the different sections. The cable was successfully laid in the spring the whole way from Fao to Karachi, with intermediate stations at Bushire, Mussendom, and Gwadur, the portion east of Gwadur having been added to the original scheme as an alternative to the Mekran coast land line. The process of laying the cable was not so simple a matter as such operations have now become. The Suez Canal had not yet come into existence, and the cable had consequently to be conveyed round the Cape of Good Hope in sailing vessels, which, during the actual laying of the cable, were towed by steamers of the old Indian Navy; the Karachi-Gwadur land line was completed; and the necessary buildings for the accommodation of the staff were erected or adapted at the different stations in Beluchistan, at Mussendom, at Bushire, and at Fao. The Baghdad-Fao line was completed in the course of the year, so that the project of a telegraph from London to India had by the end of 1864 become an accomplished fact. But there are telegraphs and telegraphs, 
and a vast amount of work had yet to be done before anything like regularity or efficiency was attained in the parts of the system not under the direct control of the Indian Government. Strange as it may appear, it was in Europe that by far the greatest difficulties existed. The lines east of Constantinople-partly, no doubt, through the smallness of the local traffic-were far more satisfactory than those to the westward. To devise and urge on the most necessary ameliorations, Colonel Stewart hurried to Constantinople as soon as the Persian Gulf cable had been laid. There, owing to the general injury to his constitution caused by the unsparing manner in which he had for years overworked himself, he succumbed to an attack of fever in January 1865. Colonel Goldsmid, with whom was associated Major Champain, succeeded him as Directorin-Chief of what had now come to be designated the Indo-European Telegraph Department, and I succeeded Major Champain as Director of the Persian section, assisted by Captain (now Colonel Sir Oliver) St. John, and the late Captain Pierson, both of the Royal Engineers, and by a detachment of twelve, afterwards increased to twenty-four, non-commissioned officers of the corps. Our position had from our first landing at Bushire, in the end of 1863 , been extremely anomalous, as it will be remembered that the Convention with Persia provided for no such executive staff, but only for the presence of one English officer, with no executive functions whatever.

It will probably, however, give a clearer idea of the subsequent history of the telegraph if I here break the chronological order of the narrative, and for a few minutes call your attention to the main physical features of Persia and the general condition of the country at the time of our arrival.

Physically, Persia may be described as a great plateau, overlooking the Caspian Sea on the north, the plains of Mesopotamia on the west, and the Persian Gulf on the south. To the north-west and to the east the plateau extends into the Armenian provinces of Turkey and Russia on the one side and into Afghanistan on the other. To reach the plateau, the plains of which are at an average elevation of 4000 to 5000 feet above the level of the sea, great mountain barriers must be surmounted, no matter from what side the approach is made. On the side of the Caspian, this barrier consists of a range of mountains known in Europe as the chain of the Elburz-a name, however, which in Persia is applied only to one particular mass of it near Teheran. On the side of the valley of the Tigris and the Persian Gulf, range after range running in a general N.W. and S.E. direction, has to be crossed before the main plateau is reached. The table-land itself is intersected by numerous ranges and detached masses of mountains, except in Eastern Persia, where great plains are the main feature. With the single exception of the provinces which lie between Elburz and the Caspian, the climate is remarkably dry. Throughout the summer little or no rain falls, there are few rivers other than mere freshets in spring-time, and most of the agriculture is carried on by artificial irrigation, which depends chiefly for its supplies on the melting of the winter snows. The temperature of the plateau is what one would expect to find 
it. under those conditions in the latitude of Persia, viz., very hot and dry in the summer, very cold and snowy in the winter, and temperate in spring and autumn. In the more elevated districts, and especially in the mountain passes, several of which our telegraph crosses at an elevation of 8000 feet above the level of the sea, the cold in winter is excessive, and the snow often such as to render all locomotion utterly impossible. The hardships, and even the dangers, attending a journey in the mountainous parts of Persia in winter, can hardly be realised by those who have not undergone them; and winter is, unfortunately, the season when the telegraph lines are most liable to damage and interruption, and when consequently such journeys have most frequently to be undertaken by those who have charge of the maintenance of the lines.

There were no carriageable roads, and wheeled vehicles were practically unknown. The roads were merely mule tracks. Merchandise was carried on the backs of camels, mules, and donkeys, and the personal baggage of travellers almost exclusively on mules. Of those useful animals and of horses there was an abundant supply of excellent quality at very moderate prices. Accommodation for caravans was to be found on most of the main roads at caravanserais, from 25 to 30 miles apart, at most of which fodder for the animals was procurable. This, however, was by no means universally the case, and at many of the caravanserais nothing but the rude shelter of the bare walls and a meagre supply of brackish water was obtainable. For all his personal wants the traveller had to carry his own supplies with him. Owing to the want of means of communication, the local governors were all but uncontrolled by the Central Government at Teheran. Each governor, so long as he held office, was supreme, even in matters of life and death, within his own province, and practically did what seemed good in his own eyes. Leaving the towns out of account, the country population consisted of about equal numbers of sedentary cultivators or rayats, and nomadic pastoral tribes or Eeliauts. The latter are a very independent and somewhat turbulent set of people. They are well armed and well mounted, and their property, consisting as it does of tents, flocks, and herds, is altogether movable. During a great part of the year, they frequent the most mountainous and inaccessible parts of the country. No wonder, therefore, that, like the highland rovers of our own country in former days, they are apt to regard robbery as a fairly legitimate means of supplying their wants and improving their lot. Under such conditions it was not surprising that the roads shonld sometimes have been infested by armed bands of robbers, who had as little scruple in taking the lives as in helping themselves to the property of those who were unfortunate enough to fall in their way. The state of a province depended in this respect almost entirely on the character of the Governor. If, like most of his countrymen, he was a man of energy and determination, the roads were wonderfully safe, while if he was a man of weak or indolent disposition, murders and robberies were of constant occurrence. Under the former class of governors robbers were unsparingly hunted down and summarily executed-sometimes, it must be confessed, in a cruel or barbarous manner. Governors of this kind were at 
least a terror to evildoers, if not always, or to the same degree, a praise and protection to them that did well.

There is an institution in Persia which even the most cursory account cannot pass without notice-the chapar or horse-post, which has probably been handed down to the present time with but little change from the days of Xerxes and Darius. Post-houses or rather post-stables, containing relays of saddle horses, are kept up at distances varying from 20 to 30 miles apart all along the main roads radiating from the capital to the extremities of the kingdom. As a rule the horses are good. A traveller who is accustomed to hard riding, and not afraid of fatigue, can by means of the chapar get over the country at the rate of 80 to 100 miles a day. He must, of course, sleep on the ground, and content himself with the barest modicum in the way of kit and provisions. Chapar is the express train of Persia, and I need hardly say that we found it extremely serviceable, and used it freely. I regard it with much respect, and I have probably had more experience of this thoroughly Persian institution than any other European, having chapared an aggregate distance of fully 25,000 miles. The fact that I should have done so without molestation, travelling as I did without escort, by day and by night, at all seasons of the year, speaks volumes for the good order which generally prevailed. Sometimes, it is true, I narrowly escaped, and all of our staff were not so fortunate as myself, several of them having been robbed and wounded, and two of them killed.

The Persians are a decidedly robust, handsome race, amply endowed with the gifts of intelligence and imagination. They are of a restless, active disposition, and in this and many other respects totally unlike what Orientals are supposed to be. Grasping and unscrupulous in the pursuit of gain, they are free and even lavish in their expenditure. The rich love to surround themselves with all that is beautiful. They live in spacious houses luxuriously and tastefully furnished. Their love of fine gardens with long vistas of flowers, shrubs, trees, and fountains, amounts almost to a passion. "Live and let live" is one of the practical mottoes of their lives. A rich man is almost invariably surrounded by a host of retainers and dependants who, with their families, live on his bounty. An acquaintance with the works of their great poets is very general. More than once, at a Persian gentleman's table, I have heard a guest either prompted to an apt quotation or corrected in a false one by one of the servants in attendance. The untruthfulness with which they are so constantly credited, is not altogether vicious. Much of it is little more than a form of politeness which ceases to deceive those who are familiar with their ways. Their ever active imagination accounts for as much more of it, as well as for the poetic and artistic instincts by which they are so eminently distinguished.

But to resume our narrative. In the course of the year 1864, a single wire line from Bushire via Teheran to the Turkish frontier, near Baghdad, had been erected on wooden posts supplied by the Persian Government. This was accomplished with the greatest difficulty, owing to the opposition of some of the local governors, who, naturally, regarded with dislike a new-fangled Feringhi invention which could not fail, in 
the end, to diminish their powers and privileges. Before the line was completed, 200 miles of it, over the most difficult part of the country had been entirely swept away by the Eeliauts at the secret instigation of the local authorities. The Convention, as was to be expected, had proved of little practical value, as it barely furnished a valid excuse for our presence in the country. After much negotiation, a second Convention was signed, which provided for our management of the line for five months, at the expiry of which period we were to hand it over to Persian officials, and at once leave the country. By the end of that time, however, in 1865, the opposition to our presence had much subsided, and towards the end of the year a Convention for five years was negotiated and signed. In 1866-67 a second wire was added, to be used exclusively for Indian traffic. The protection of the line and its prompt repair in cases of interruption were our great difficulties. For the latter, the system, finally adopted after several others had failed, was as follows: At towns or villages, or other suitable places, 50 to 80 miles apart, control stations were established, each of them in charge of a European clerk with two Persian gholams or horsemen, who had been thoroughly trained as linesmen. At stated hours the clerks placed their instruments in circuit and at once saw if everything was all right. If anything was wrong the fault was at once localised, and a gholam despatched from each of the control stations, on either side of the fault, with orders to ride rapidly along the line until he had reached and repaired the fault, and until he had met the gholam coming from the other station. As the gholams provided their own horses they had a direct interest in keeping their sections in good order so as to diminish, as much as possible, the frequency of the rapid journeys which they had to make.

It will be remembered that communication had been opened, rid Baghdad in the end of 1864. A stream of telegrams at once poured in daily. But the want of efficiency in the lines across Europe and Asiatic Turkey, to which I have already referred, caused great delay and confusion in their transmission. This was only aggravated when, in 1866, the Russian and Persian Governments joined their local lines at the Perso-Caucasian frontier and announced to the commercial world that a new route for Indo-European messages had been established via Russia. On neither the Russian line nor the local Persian one, under Persian employes, from the frontier to Teheran, was there a staff in any way competent to deal with international English telegrams. The state of confusion in which the messages reached or did not reach their destinations was something appalling. Delay and mutilation were bad enough, but what was perhaps still worse was the hopeless confusion of dates. A message (dated say the 1st of the month) might, as probably as not, be overtaken and passed on the road by a message to the same place dated the 2nd, 3rd, or 4th. A merchant at Calcutta or Bombay might, by a happy accident, get a telegram giving him the London prices of the day before, while his neighbour's latest, received at the same time, might be a week or ten days old. This intolerable state of things led the eminent engineering firm of Siemens Bros, at the head of which was the late President of the Royal Society, Sir William Siemens, to conceive the idea 
of a special through line from London to Teheran, to be made and worked by an English company for the transmission of Indo-European messages alone. The firm had large branches in Berlin, St. Petersburg, and Tiflis, where they were well and favourably known by the German and Russian Governments. This fact, no doubt, facilitated their obtaining, as they did in 1867, concessions from those Governments to construct and work a line, on certain conditions, across Germany and Russia, exclusively for messages to and from India. A similar concession was obtained from Persia for the section between the Russian frontier and Teheran. An English company, called the Indo-European Telegraph Co., was then formed to take over the concessions and carry them into effect. With as little delay as possible, work was begun, and in the spring of 1870 , an excellent specially constructed line, with two conductors, worked throughout by English clerks, was opened for traffic between London and Teheran, where it joined our Government lines, to which I have already referred.

While the Indo-European Company's lines were being constructed another company was formed in London for the purpose of laying a submarine line the whole way from England to India. Like the IndoEuropean Company, the Eastern was called into being by the hopeless state of confusion in the existing lines west of Teheran and the head of the Persian Gulf. Had the communication over those lines been better than it was, possibly neither the Indo-European nor the Eastern Company would have come into existence. In this case good arose from, and was due to, excess of evil. Submarine telegraphy had, since the former failure of the Red Sea route, made enormous strides, thanks chiefly to the brilliant and eminently practical genius of our distinguished conntryman, Sir Wm. Thomson. The result justified the confidence of the founders of the Eastern Company in the success of their scheme, and almost simultaneously with the opening of the Indo-European Company's line to Teheran came the opening of the Eastern Company's to Bombay. From that time to the present day, a period of nearly nineteen years, telegraphic communication with India has been regular, rapid, and unintermittent. Had either of the companies been established alone in 1870 , the other would possibly, perhaps probably, never have come into existence. As it is, Government and the public have the great advantage and the great security of two entirely different telegraphic systems uniting the Indian Empire with the metropolis, viz., the Indo-European viâ Lowestoft, Emden, Berlin, Warsaw, Odessa, Kertch, Tiflis, Teheran, Bushire, and Karachi ; and the Eastern with two cables viâ Falmouth, Gibraltar, Malta, Suez, Aden, and Bombay. To these must be added the original ronte through Baghdad and Constantinople.

To bring the history down to the present day, but little remains to be said. The Mekran coast land line was, many years ago, extended to Tashk, near the mouth of the Persian Gulf, to which place also was transferred the submarine cable station formerly at Mussendom on the opposite Arab coast. From Jashk to Bushire a second cable has existed for the last twenty years.

In Persia iron standards were substituted throughout for the old 
wooden poles, the constant renewal of which in a comparatively treeless country was a perpetual source of trouble, anxiety, and expense. Our Convention and the Indo-European Company's concession have both been modified and their term extended for a lengthened period of years.

A whole lecture might be devoted to the history of the regulation of international telegraphy, the necessity for which became gradually apparent to all the States of Europe. In the framing and revising of these regulations at the periodical international conferences, the late Director-in-Chief of the Indo-European Telegraph Department, Colonel Sir John Bateman-Champain, took a conspicuous and eminently useful part. But this, as well as the question of tariffs, is too large and complicated a subject to be more than hinted at on the present occasion.

Of the efficiency attained by the telegraphic service between this country and India, you may judge for yourselves by the few following facts:- Some considerable time after through-communication had been opened, a hope was expressed (in 1867, to the best of my memory) that the service might eventually be so improved that telegrams would reach their destination correctly and regularly within a maximum of three days from their original dates. This opinion, however, was thought at the time to be too Utopian. Messages between all parts of the United Kingdom and all parts of India (not merely those between London and the Presidency towns) now reach their destinations within an average interval between their reception at one end and their delivery at the other, of less than an hour and a half. In an average of only one word in about two hundred does even the most trivial mistake occur in transmission. And it must be remembered that the telegrams are almost entirely either in code or cipher, which, as compared with ordinary language, adds enormously to the chances of error, as well as to the time required for transmission. Were this degree of speed and accuracy attained with a small amount of traffic, it would still, I think, bear favourable comparison with that of any telegraph system in the world. But the traffic to which those averages apply amounts to the large total of nearly 1000 messages a day.

Of the far-reaching effects which this constant stream of rapid communication has had, and has, on the Government, the commerce, and the general condition of India, I shall not attempt to form an estimate. One effect on this country is patent to all, viz., the greater and more widelyspread knowledge of India, and the greater interest taken in her affairs. Every noteworthy event is at once telegraphed to the press at home, and in every Monday's copy of the Times appears an exhaustive summary of the week's Indian news accompanied by such commentary as the events seem to call for. It may perhaps surprise you to be told that those interesting telegrams are altogether unpadded, and that even to the punctuation-the use of inverted commas for instance-they are printed absolutely verbatim.

The effect of our telegraph in Persia has been very considerable. By it, and by the numerous other lines of which it has been the parent, the powers of the local governors have been much curtailed and brought 
directly under the control of the Shah and his Ministers at Teheran. Oppression has thereby certainly diminished. By means of the telegraph Persia has been brought practically within the community of European States. She now has regular diplomatic relations by means of embassies and legations with Great Britain, Russia, Turkey, France, Germany, Austria, Italy, and the United States of America. A regular postal system has been organised, with a bi-weekly post to Europe, and a weekly one from Teheran to India and all parts of Persia. A participator from the beginning in the International Telegraph Convention for the regulation of international telegraphy, Persia has for a good many years been also a member of the Postal Union. A beginning has been made in the construction of carriageable roads in the neighbourhood of Teheran, where also a short railway six miles in length has recently been opened. As announced by the Prime Minister at the Mansion-house, the Shah has this year opened to the navigation of all countries the only navigable river in his dominions, the Karun, an affluent of the Shat el Arab, into which it flows near the town of Mohammerah. These and many other signs of progress that could be enumerated are in great measure due to the successful establishment and maintenance of our telegraph in Persia during the last twenty-five years, and more especially to the good relations which have so long subsisted between our telegraph staff and all ranks and classes of the people.

While thus attributing to the Telegraph a large share in the improved Government and slow but steady progress of Persia during the last quarter of a century, it would be altogether misleading and unjust if I inferred that it was the sole, or even the principal, cause of the forward movement that is going on. That cause must be sought for in the high intelligence of the Persian people, and in the liberal and patriotic spirit of the Sovereign who has ruled over the land for the last forty years.

It is, I think, worthy of record that the long and constant intercourse between our telegraph staff and all sorts and conditions of men in Persia, instead of begetting, as it might easily have done, mutual aversion and ill-will, has had the very opposite effect. For many years the relations of our staff with the Persians of all classes have been of the most friendly character. When you remember that our English staff, numbering fifty or sixty individuals, is scattered all over the country, along a line of 1300 miles, many absolutely alone so far as other Europeans are concerned, and all brought by the nature of their duties into constant contact with the rulers and people of the country, I think you will agree with me that the friendly feelings and mutual good offices which prevail are highly creditable to English and Persians alike. We have always endeavoured to act on the principle of conducting ourselves towards the Persians, in social as well as business matters, as if they were our fellow-countrymen, and they have certainly responded in a generous and hospitable manner. Speaking personally, I am happy to count among them some of my best friends, and I look back with pleasure on my long residence of over twenty years in their country, in whose independence and welfare I shall always take the deepest interest. 